\title{
Injuries caused by lactobacillus SP, candida SP and trichomonas vaginalis in the female genital tract
}

\begin{abstract}
Vulvovaginitis is one of the most troublesome and common gynecological problems affecting a woman's health. Vulvovaginitis can be defined as inflammations that affect the vaginal walls causing local $\mathrm{pH}$ changes, pruritus and sometimes secretions. They are caused by bacteria (bacterial vaginosis), fungi (fungal vulvovaginitis), protozoa (trichomoniasis) and also by associated microorganisms called mixed vulvovaginitis. Lactobacillus sp; are responsible for the determination of acid $\mathrm{pH}$ by inhibiting bacterial species that attack the vaginal mucosa. If there is an imbalance in the vaginal microbiota, women begin to present pictures of infections by different microorganisms. The main infectious vaginitis, which affects mainly women of reproductive age, are caused by microorganisms: Lactobacillus $\mathrm{sp}$, Candida sp, and Trichomonas vaginalis
\end{abstract}

Keywords: bacterial vaginosis, lactobacillus $\mathrm{sp}$, candidiasis, candida $\mathrm{sp}$, trichomoniasis, trichomonas vaginalis
Volume 4 Issue 5 - 2017

\author{
Vieira D,' Barbosa FR,' Sousa FC,' Freitas \\ $\mathrm{KO},{ }^{\prime}$ Silva RC,' Taufner $\mathrm{GH},{ }^{2}$ destefani $\mathrm{AC}^{3}$ \\ 'Biomedicine Graduate Student of Course of the Faculty of \\ Biomedical Sciences of Espírito Santo, Brazil \\ ${ }^{2}$ Biomedic, Master student in Biotechnology from the Federal \\ University of Espírito Santo (UFES), Brazil \\ ${ }^{3}$ Professor of the Biomedicine Course of the Faculty of \\ Biomedical Sciences of Espírito Santo, Brazil
}

Correspondence: Afrânio Côgo Destefani, Professor of the Biomedicine Course of the Faculty of Biomedical Sciences of Espírito Santo, Cariacica/ES, Rua Bolivar de Abreu, 48, Campo Grande, Cariacica/ES, Zip code 29.l46-330, Brazil, Tel +5527999434083, Email afraniocd@gmail.com

Received: March 23, 2017| Published: April 05, 2017

\section{Introduction}

Vaginitis, the main complaint in gynecological consultations, refers to a variety of inflammatory disorders of the lower genital tract, characterized by a triad of symptoms such as vulvovaginal pain, pruritus, and burning, which may be secondary to infection, irritation, allergy or systemic disease. It is an infectious process of the female inferior genitourinary tract, important in the medical clinic, due to a large number of consultations in the public and private clinics. ${ }^{1,2}$ They are caused by bacteria, fungi, protozoa and also by associated microorganisms called mixed vulvovaginitis. ${ }^{3}$ According to Andrioli et al., ${ }^{1}$ Dalazen et al., ${ }^{4}$ and Queiroz et al., ${ }^{5}$ this type of disease mainly affects women of childbearing age, affecting $75 \%$ of women at least once during life, it is a situation that causes great discomfort for the woman, and may even lead to psychological disorders. Yeasts of the genus Candida sp. are common agents that colonize the mucosa, skin and gastrointestinal tract, the most frequently isolated species in the vaginas of symptomatic patients is Candida albicans, because it is an opportunistic microorganism, under certain conditions there may be a greater virulence of the fungus or an imbalance of the immunity of the Host, making it pathogenic Figure 1.
In addition to the presence of Candida sp. in the vagina, it is also possible to find in the vaginal microbiota Lactobacillus sp. which are a group of bacteria that are found in the cervix-vaginal region, these are responsible for controlling vaginal $\mathrm{pH}$, therefore, when there is a concentration deficit of Lactobacillus sp. In the vaginal microbiota, it is possible that other agents appear and begin a pathological process. When there is an increase in the population of anaerobic bacteria it is possible that a picture of bacterial vaginosis appears due to this imbalance of the microbiota. ${ }^{3}$ According to Lima et al., ${ }^{6}$ in the female genital tract, it is possible to find the parasite Trichomonas vaginalis colonizing the vagina and ectocervix. This parasite colonizes the epithelia of the genitourinary tract of men and women, causing the trichomoniasis that is a sexually transmitted parasitosis. One of the main features of this parasitosis is the appearance of severe inflammation (vaginitis) usually present discharge due to leukocyte infiltration, abnormal odor, and vulvar pruritus. The vagina and cervix may have lesions and hemorrhagic points. It is recommended that the diagnosis of vaginal infections should not be based solely on clinical data and that microbiological examinations such as culture and drug susceptibility testing should be incorporated, when possible, as complementary to the diagnosis of vulvovaginitis Figure $2 .^{2,7}$

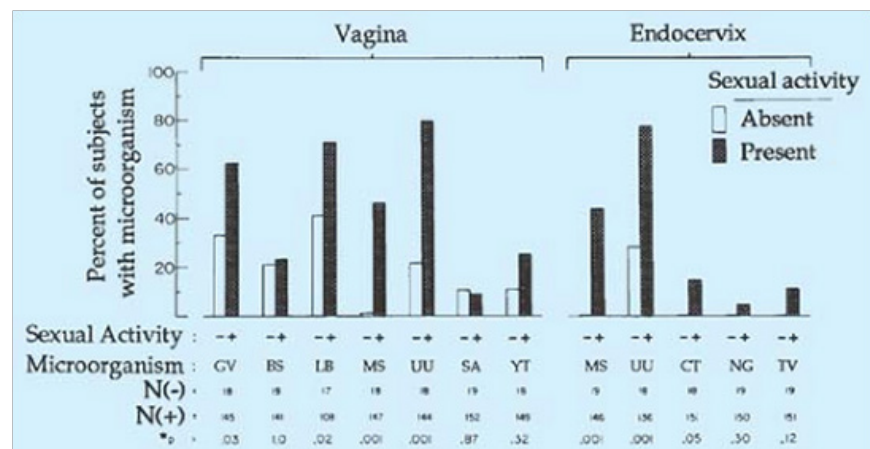

Figure I Microbiologic isolations from vagina and endocervix in adolescent girls by presence or absence of sexual activity.

BS group, B Streptococcus; CT, chlamydia trachomatis; GV, gardnerella vaginalis; LB, lacto bacillus; MS, mycoplasma species; NG, neisseria gonorrhoeae; SA, staphylococcus aureus; TV, trichomonas vaginalis; $\mathrm{UU}$, ureaplasma urealyticum; $\mathrm{YT}$, yeast.

*Chi-square statistic except for CT, NG, and TV Fischer exact test. 


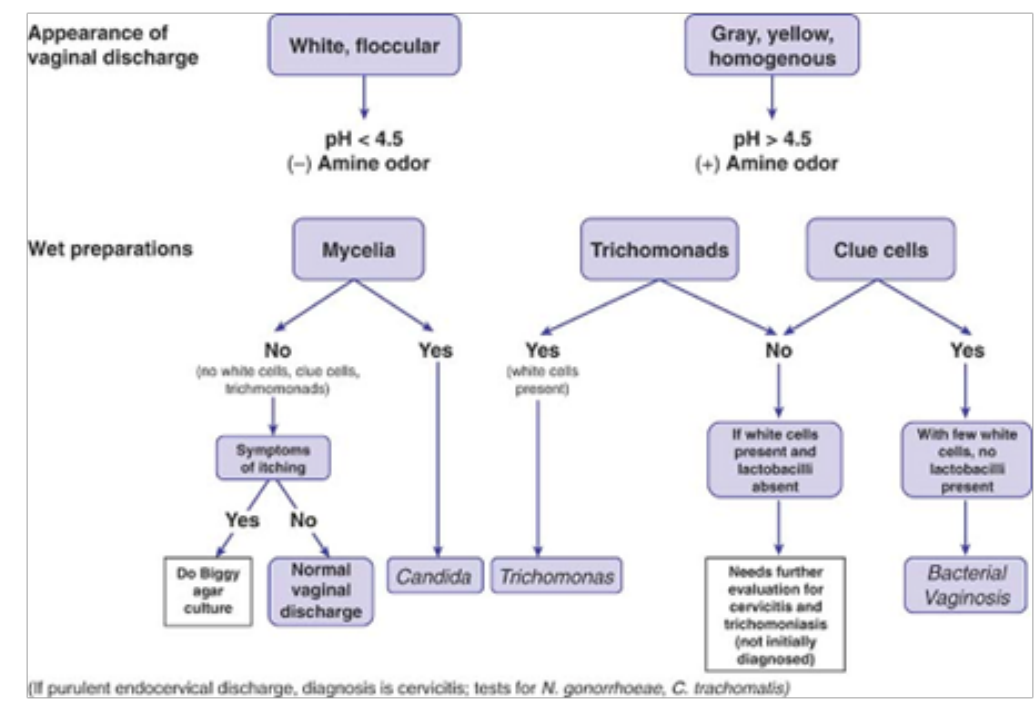

Figure 2 Differential diagnosis of vaginitis.

\section{Lactobacillus SP}

Lactobacilli are microorganisms of the intestinal microbiota, known for their beneficial effects on human health, being called probiotic bacteria. Probiotic bacteria colonize predominantly the colon but may have beneficial effects not only in the large intestine but also in the small intestine and other parts of the body, including systemic immune-mediated effects. They colonize more colonized infants exclusively breastfed. This point is of great importance, considering that the composition of the colonic microbiota tends to be stable throughout the life, being defined in the first months of life. Another fundamental point for the composition of the colonic microbiota is the type of delivery (vaginal or cesarean) that represents the first influence of the environment on the composition of the intestinal microbiota. In later life, exposure to inappropriate environmental conditions may lead to tropical (environmental) enteropathy. Tropical enteropathy can be defined as diffuse subclinical atrophy of the villi of the small intestine, associated with inflammatory T-cell infiltration. ${ }^{8}$ According to Brooks, ${ }^{9}$ shortly after birth, aerobic lactobacilli appear in the vagina and persist while the $\mathrm{pH}$ remains acidic (several weeks). When the $\mathrm{pH}$ becomes neutral (remaining thus until puberty), the presence of a mixed microbiota of cocci and bacilli is verified. At puberty, aerobic and anaerobic lactobacilli reappear in large numbers and contribute to the maintenance of acid $\mathrm{pH}$ with the production of acid from carbohydrates, in particular, glycogen. It is apparently an important mechanism to prevent the establishment in the vagina of other possibly harmful micro-organisms. If lactobacilli are suppressed by the administration of antimicrobials, the number of yeast or various bacteria will increase, causing irritation and inflammation. Bacterial vaginosis is a syndrome characterized by drastic changes in species in the vaginal microbiota and their relative proportions. Changes occur, from a healthy vaginal ecosystem, characterized by the presence of lactobacilli, to a state of disease characterized by the presence of microorganisms belonging to the phyla Bacteroidetes and Actinobacteria. After menopause, the number of lactobacilli again decreases and a mixed microbiota reappears. The normal vaginal microbiota includes group B streptococcus in approximately $25 \%$ of women in the pregnancy period. During childbirth, the child may acquire group B streptococcus, which can subsequently cause neonatal sepsis and meningitis. The normal vaginal microbiota also includes $\alpha$-hemolytic streptococci, anaerobic streptococci (peptoestrecocos), Prevotell species, Clostridium, Gardnerella vaginalis, Ureaplasma urealyticum, and more rarely species of Listéria or Mobiluncus. The cervical mucus has antibacterial activity and contains lysozyme. In some women, the vaginal introitus contains a dense microbiota that resembles the microbiota of the perineum and perineal area, which may be a predisposing factor in recurrent urinary tract infections. The vaginal microorganisms present at birth can infect the newborn (group B streptococcus).

Bacterial vaginosis (BV) is a disorder of the vaginal ecosystem of polymicrobial etiology, in which there is a predominance of anaerobic microorganisms. It is the most frequent cause of genital discharge, responsible for 40 to $50 \%$ of the cases, and about half of the female carriers are asymptomatic. ${ }^{10}$ Bacteria that inhabit the vagina are an important defense barrier of the body, representing a complex microbiological system, with about 109 bacterial colony forming units per gram of secretion and dozens of different species. Lactobacilli producing the hydrogen peroxide $\left(\mathrm{H}_{2} \mathrm{O}_{2}\right)$ show in vitro the ability to inhibit various bacteria, including Gardnerella vaginalis, anaerobes, Neisseria gonorrhoeae, among others. The proliferation of bacteria such as Gardnerella vaginalis and Mobiluncus sp, uncommon in the normal vaginal flora, results in a marked reduction of Lactobacillus or Doderle in Bacilli and elevation of vaginal $\mathrm{pH}$ above 4.5, leading to the appearance of BV symptoms. BV is associated with an increased risk of HIV infection. Women from countries with a high frequency of HIV-AIDS, such as Uganda, have a prevalence of BV over $50 \% .^{10}$

Studies show that one of the most relevant risk factors for BV is the use of intrauterine device (IUD). Other predisposing factors 
would be new or multiple sexual partners, use of vaginal douches, oral sex, sex during menses, among others. The use of barrier methods and oral contraceptives seems to protect against BV. ${ }^{10}$ According to Camargo et al. ${ }^{11} \mathrm{BV}$ is the most common cause of vaginal discharge, with a prevalence varying from 9 to $41.5 \%$, and may present with foul-smelling vaginal discharge or no symptoms. There is evidence of considerable morbidity associated with $\mathrm{BV}$, as a higher risk of postpartum infection, post abortion and post hysterectomy; have a higher risk of preterm birth. It is also considered a risk factor for the acquisition and transmission of Human Immunodeficiency Virus (HIV), Simple Herpes Virus type 2 (HSV-2), gonococcus and chlamydia, as well as for the development of Pelvic Inflammatory Disease (PID) Figure 3.12

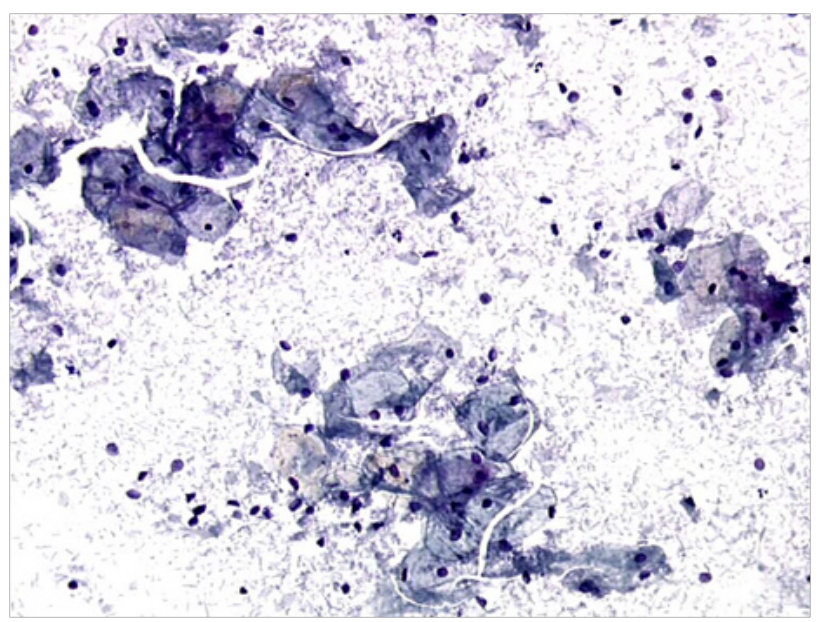

Figure 3 Luteal phase with abundant lactobacilli and cytolysis (nude nuclei and cytoplasmic remains in the fundus) and basophilic squamous cells with folded cytoplasm. (10x objective).

\section{Candida SP}

Yeasts of the genus Candida are part of the normal human microbiota, and can be found in the skin, in the mucosa, and in the gastrointestinal tract. ${ }^{1}$ There are approximately 200 different species of yeast, these fungi colonize the mucous membranes from birth, always causing the risk of endogenous infection..$^{13}$ The main species of clinical interest in this genus are Candida albicans, C. glabrata, C. krusei, C. parapsilosis and C. tropicalis. ${ }^{4}$ Being Candida albicans is a dimorphic fungus, which presents in yeast forms, being associated with asymptomatic colonization and filamentous, observed in pathogenic processes. ${ }^{13}$ According to Alvares et al., ${ }^{13}$ Dalazen et al., ${ }^{4}$ Koss et al. ${ }^{14}$ and Rodrigues et al., ${ }^{2}$ the presence of the fungus, most of the time, does not present symptoms, only when there is an imbalance in the relation between the host and Candida sp. that the parasitic relationship is manifested, causing infections called candidiasis, this type of infection varies from superficial lesions in healthy people to disseminated infections in immunocompromised patients. Cases are mainly recorded in pregnant, diabetic patients who have received prolonged microbial therapy or who use oral contraceptives.

The main symptomatologies associated with this pathology are thick secretions with whitish coloration, besides pruritus and burning in the vulvar region, these symptoms are characteristic of a vulvovaginal candidiasis (VVC) that occurs mainly among women of reproductive age and menopause, asymptomatic forms are more associated with C. non-albicans species, VVC occurs mainly in the vulvar region, vaginally and, more rarely, in the cervix. It is the second cause of acute vaginitis, after bacterial vaginosis, as there are no clinical manifestations that are characteristic for VVC, it becomes necessary to perform laboratory tests for the isolation and identification of the pathogen since the symptomatology of this infection is not characteristic for VVC. According to Lima, ${ }^{15}$ reproductive tract infections present precarious prevention, diagnosis, and treatment services. The cytopathological examination, in addition to identifying inflammatory changes and neoplastic lesions in the uterine cervix, has been an important tool in the identification of alterations in the vaginal flora. The predisposing factors of the host are well studied and consequently known, at least in part, by professionals working with women's health Figure $4 .^{12}$

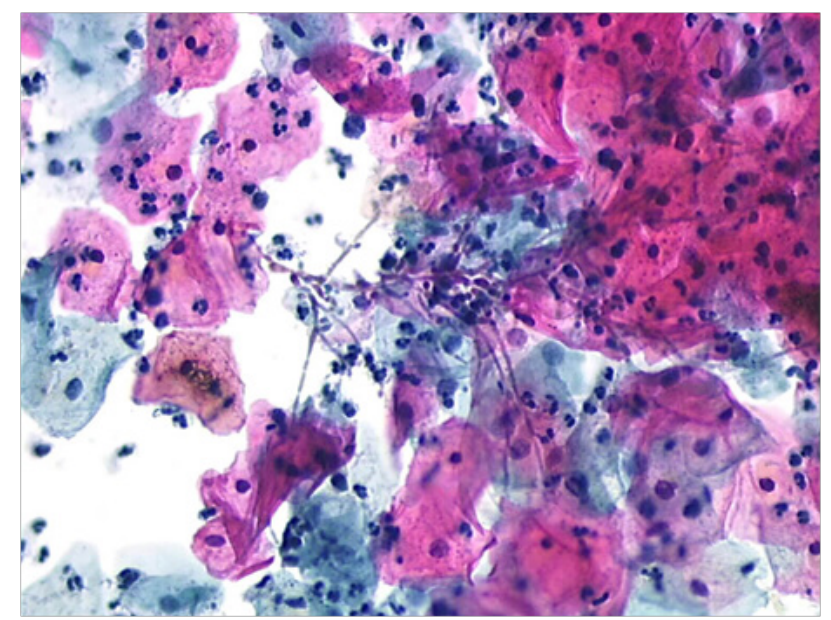

Figure 4 Moniliasis (Candida albicans): hyphae and spores on inflammatory background. (20x objective).

\section{Trichomonas vaginalis}

Trichomonas vaginalis is an anaerobic protozoan, a normal inhabitant of the vagina in women and in the urethra in some men and is usually sexually transmitted. When vaginal acidity changes, these protozoa increase its population causing trichomoniasis. ${ }^{16}$ Trichomoniasis, a disease caused by this parasite, presents a wide range of clinical manifestations, ranging from asymptomatic to the most severe, and has been associated with transmission of HIV, pelvic inflammatory disease, cervical cancer, infertility, preterm birth and low birth weight of infants born to infected mothers. In order for the manifestations of the diseases caused by this parasite to occur, it is necessary that the human organism is undergoing immune weakening, that the parasite load is large in quantity and aggressiveness, as mentioned by Maciel et al. ${ }^{17} \mathrm{~T}$. vaginalis mainly infects the squamous epithelium of the genital tract. The discharge, which is the product of the clinical manifestations of this parasite, presents a yellowish, abundant, foamy and mucopurulent appearance, with abnormal vaginal odor and vulvar pruritus. ${ }^{17}$

A study carried out in the city of Sergipe, Brazil, by Almeida et al. ${ }^{18}$ showed that the majority of the cases that confirmed the disease were female, with ages ranging from 19 to 44 years, and most of them in incomplete basic schooling, in agreement with the studies of other authors mentioned in the article. Vaginitis, whether infectious or not, is one of the most common problems in clinical medicine and is one of the main reasons why women seek a gynecologist. Bacterial vaginosis, candidiasis, and trichomoniasis account for $90 \%$ of cases of infectious 
origin. Bacterial vaginosis is characterized by the replacement of vaginal flora, usually dominated by lactobacilli, by a complex and abundant flora of strictly or facultatively anaerobic bacteria normally found in the vagina. ${ }^{19}$ According to Camargo et al., ${ }^{11}$ several tests can be used for the diagnosis of vulvovaginitis. The available methods include the clinical criteria described by Amsel for the diagnosis of $\mathrm{BV}, 1$ which includes the clinical characteristics and the fresh examination of the vaginal secretion to identify the lane cells; $\mathrm{pH}$ evaluation and odor testing. The fresh examination of vaginal contents is also used to identify fungi and Trichomonas. The classification of the microbial flora in the Gram-stained smear is another available method, described by Spiegel in 1983, modified by Nugent in 1991 and simplified by Ison and Hay in 2002. The culture can be used for identification of fungi and Trichomonas. In addition, molecular tests for the diagnosis of BV, candidiasis, and trichomoniasis are currently available. Pap smears were also evaluated as a tool to diagnose vaginal infections/ infestations and vaginal flora alterations, due to their widespread use, ease of performance and low cost. The treatment of vaginitis should involve the identification and correction of any underlying condition responsible for the inflammation. If there is evidence of sepsis, appropriate antibiotic therapy based on culture results and sensitivity tests should be instituted Figure 5. ${ }^{12,20}$

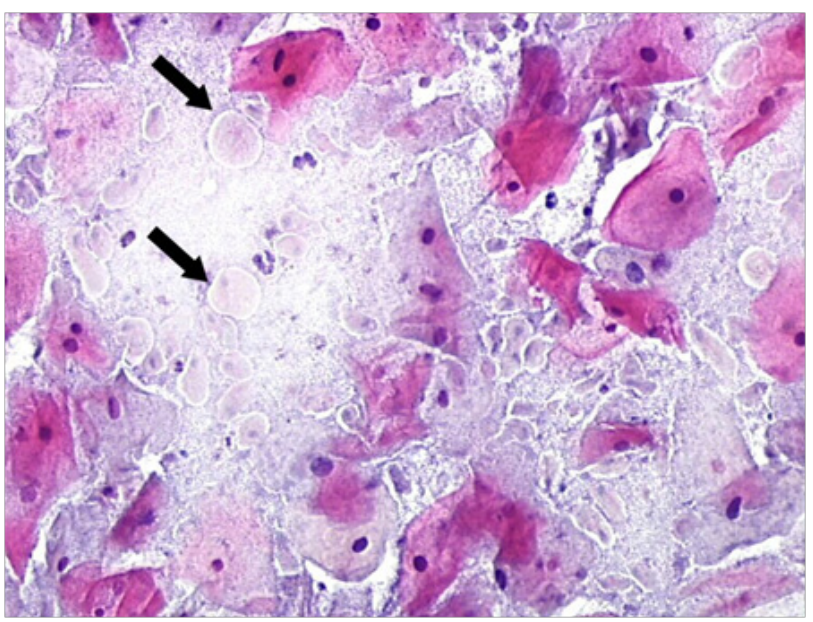

Figure 5 Inflammatory ectocervix: dirty bottom, Trichomonas vaginalis infection (arrows: visible parasites). (20x objective).

\section{Conclusion}

Vaginitis is a pathological process by which the body passes through infection by etiological agents: Lactobacillus (mainly Gardnerella vaginalis), Candida sp and Trichomonas vaginalis, posing a health risk, especially for women. Thus, prevention becomes a key factor in avoiding contamination by these agents. The main ways of prevention are proper hygiene, use of condoms, avoid tight clothing, avoid the use of sprays and other products that cause vaginal irritation. As for cytology, it has been shown that the cytological examination, in addition to being used primarily for the evaluation of possible precursor lesions of cervical cancer, is also used for the detection of infectious agents that cause vaginitis and represents a test of great value for public health care besides being a low-cost exam.

\section{Acknowledgements}

None.

\section{Conflict of interest}

The author declares no conflict of interest.

\section{References}

Andrioli JL, Oliveira GS, Barreto CS, et al. Frequência de leveduras em fluido vaginal de mulheres com e sem suspeita clínica de candidíase vulvovaginal. Rev Bras Ginecol Obstet. 2009;31(6):300-304.

2. Rodrigues MT, Gonçalves AC, Alvim MC, et al. Associação entre cultura de secreção vaginal, características sociodemográficas e manifestações clínicas de pacientes com diagnóstico de candidíase vulvovaginal. Rev Bras Ginecol Obstet. 2003;35(12):554-561.

3. Costa GP. AVALIAÇÃO DE PREVALÊNCIA DE VAGINITES INFECCIOSAS CAUSADAS POR Gardinerella vaginalis, Trichomonas vaginalis E Candida sp EM MULHERES CADASTRADAS NO ESF I DA CIDADE DE LAGOA GRANDE. Brazil: MINAS GERAI; 2012.

4. Dalazen D, Zanrosso D, Wanderley L, et al. Comparação do perfil de suscetibilidade entre isolados clínicos de Candida spp. orais e vulvovaginais no Sul do Brasil. J Bras Patol Med Lab. 2011;47(1):33-38.

5. Queiroz FJ, Gonçalves AK, Cavalcante GB, et al. Eosinofilia no sangue periférico de mulheres com candidiase vaginal recorrente. Rev Bras Ginecol Obstet. 2013;35(10):453-457.

6. Lima MC, Albuquerque TV, Neto AC, et al. Prevalência e fatores de risco independentes à tricomoníase em mulheres assistidas na atenção básica. Acta Paul Enferm. 2013;26(4):331-337.

7. Berlan ED, Emans SJ, O'brien RF. Vulvovaginal complaints in the adolescent, fastest obstetric, gynecology and pediatric insight engine; 2017.

8. Mello MP, Morais MB, Tahan S, et al. Lactobacilos e bifidobactérias nas fezes de crianças escolares de dois estratos socioeconômicos: moradores em uma favela e alunos de uma escola particular. Jornal de Pediatria. 2009;85(4):307-314.

9. Brooks GF. Microbiologia Médica de Jawetz, Melnick e Adelberg. 26th ed. Brazil: AMGH Editora Ltda; 2014.

10. Leite SF, Amorim MM, Calábria WB, et al. Perfil clínico e microbiológico de mulheres com vaginose bacteriana. Rev Bras Ginecol Obstet. 2010;32(2):82-87.

11. Camargo KC, Alves RR, Baylão LA, et al. Secreção vaginal anormal: Sensibilidade, especificidade e concordância entre o diagnóstico clínico e citológico. Rev Bras Ginecol Obstet. 2015;37(5):222-228.

12. Frappart L, Fontanière B, Lucas EE, et al. Histopatologia e citopatologia do colo uterino - Atlas Digital. Brazil; 2004.

13. Álvares CA, Svidzinski TI, Consolaro ME. Candidíase vulvovaginal: fatores predisponentes do hospedeiro e virulência das leveduras. J Bras Patol Med Lab. 2007;43(5):319-327.

14. Leopold GK, Claude G. Introdução à Citopatologia ginecológica com correlações histológicas e clínicas. Brazil; 2006.

15. Lima TM, Teles LM, Oliveira AS, et al. Corrimentos vaginais em gestantes: comparação da abordagem sindrômica com exames da prática clínica da enfermagem. Rev Esc Enferm USP. 2013;47(6):1265-1271.

16. Tórtora GJ, Funke BR, Case CL. Microbiologia. 10th ed. Artmed, Brazil; 2012.

17. Maciel GP, Tasca T, Carli GS. Aspectos clínicos, patogênese e diagnóstico de Trichomonas vaginalis. Rev Bras Patol Med Laboratorial. 2004;40(3):153-160. 
18. Almeida MS, Argôlo DS, Almeida JS, et al. Tricomoníase: prevalência no gênero feminino em Sergipe no biênio 2004-2005. Ciênc Saúde Coletiva. 2010;15(Suppl 1):1417-1421.

19. Adad SJ, Lima R, Sawan ZT, et al. Frequência de trichomonas vaginalis, candida sp e gardnerella vaginalisem esfregaços cervicais-vaginal em quatro décadas diferentes. São Paulo Med J. 2001;119(6):200-205.

20. Raskin RE. Citologia Clínica de Cães e Gatos. 2nd ed. Brazil: Elsevier Editora Ltda; 2011. 